\title{
Hormone Receptor/HER2 Positive
}

National Cancer Institute

\section{Source}

National Cancer Institute. Hormone Receptor/HER2 Positive. NCI Thesaurus. Code

C118311.

A finding indicating that the neoplastic cells in a breast cancer tissue sample test positive for estrogen, progesterone, and HER2 receptors. 